Bull. Mater. Sci., Vol. 21, No. 5, October 1998, pp. 421-425. (C Indian Academy of Sciences.

\title{
Acid resistant one coat enamel for power generation plants
}

\author{
SOMESWAR DATTA \\ Central Glass and Ceramic Research Institute, Jadavpur, Calcutta 700 032, India
}

MS received 5 December 1997; revised 27 July 1998

\begin{abstract}
A special vitreous enamel coating suitable for use in air preheater heating elements (waste heat recovery system) in boilers of thermal power plants has been developed. The preparation of coating materials, techniques of application, evaluation and characterization of the coating and prediction of life expectancy using a mathematical model based on Brandon's method have been reported.
\end{abstract}

Keywords. Vitreous enamel; coating; corrosion; mathematical model; heat recovery system.

\section{Introduction}

Thermal power generation plants, run by coal or oil, containing varying amounts of sulphur, discharge flue gases containing corrosive sulphur dioxide/trioxide gases in the atmosphere. Some parts of these gases also react with atmospheric moisture and produce corrosive condensates, e.g. sulphuric acid (Kraaijveld and Gazo 1988). This creates environmental pollution (Bouse et al 1980; Kraaijveld and Gazo 1988; Ahmad et al 1991). As a fallout, due to the high cost of fuel, development of coating materials for heat recovery system which can withstand corrosive effect of hot flue gases has been receiving considerable attention.

With the increasing demand for pollution control as well as necessity of recovery of energy from the waste heat, modern power generation plants are being equipped with waste heat recovery system using air preheater installation (Bouse et al 1980). This serves both as heat exchangers and desulphurizers of flue gases with the formation of acidic condensates. The materials for air preheater heating elements reported to be used are panels of mild steel, aluminium, titanium and corten steel but the acidic condensates cause corrosion of such heating elements and reduce their service life (Bouse et al 1980).

Acid resistant vitreous enamel coated mild steel panels for air preheater heating elements have been reported to find good potentiality to solve this corrosion problem (Phipps 1985). The selectivity of the material is based on smooth glass like surface, resistance to residue build up, durability at higher working temperatures, nonflamability and ease of replacement.

This paper describes the preparation, application, evaluation and characterization of a ceramic coating which can be applied directly on mild steel surfaces with a thin $(80-120 \mu)$ coating specially required for heat ex-

*Author for correspondence changer. The properties of the coating as compared with various test specifications adopted by different countries have been reported. The expected life time of such a thin coating for air preheater installation has been estimated using a mathematical model. The coating has been characterized by X-ray, optical and scanning electron microscopic studies. Various possible areas of application of such coating system have been identified.

\section{Experimental}

The coating compositions (shown in table 1) were based on inorganic oxides and were prepared by the frit manufacturing process commonly in use and were applied on pre-cleaned mild steel surface by conventional vitreous enamelling technique (Andrews 1961).

The approximate oxide compositions of various constituent oxides of the coating system which were studied during this investigation are given (in wt\%) as follows: $\mathrm{SiO}_{2} 45 \cdot 5-56 \cdot 0 ; \mathrm{Na}_{2} \mathrm{O} 9 \cdot 0-21.0 ; \mathrm{B}_{2} \mathrm{O}_{3} 7 \cdot 5-18.2 ; \mathrm{TiO}_{2}$ $5.0-10 \cdot 0 ; \mathrm{BaO} 0 \cdot 0-3 \cdot 0 ; \mathrm{K}_{2} \mathrm{O} 1 \cdot 0-3 \cdot 3 ; \mathrm{Li}_{2} \mathrm{O} 0 \cdot 0-1 \cdot 3 ; \mathrm{CaO}$ $0.0-1 \cdot 8$; $\mathrm{NiO} 0 \cdot 2-1 \cdot 0$; $\mathrm{CoO} 0 \cdot 2-0 \cdot 8$ and $\mathrm{MnO}_{2}$ 0.51.5 .

Commercially available pure grade raw materials (various oxides or their corresponding carbonates or nitrates along with a certain amount of fluorides) were used to make batches for preparation of coating materials. The batch of the thoroughly mixed raw materials was charged into a preheated ceramic crucible at about $1200^{\circ} \mathrm{C}$ in an experimental oil fired furnace and melted at about $1300^{\circ} \mathrm{C}$. The molten mass was stirred for homogenization and after holding for about an hour, poured in cold water to yield glassy flakes of the coating material called 'frit' which was then dried and stored for future use. The average yield of frit was about $75 \%$ and depended on the raw materials used.

For application of the coating, the frit was milled 
along with certain mili-additives to yield a thick slurry called 'slip'. Rheological properties of coating slips were studied for application on metal surface by dipping or spraying technique. To undertake such studies, the milling of frit $(300 \mathrm{~g})$ in each case was carried out in a porcelain milling jar $(1.5 \mathrm{l})$ using $600 \mathrm{~g}$ large (dia $\sim 50 \mathrm{~cm}), 800 \mathrm{~g}$ medium (dia $\sim 25 \mathrm{~cm}$ ) and $600 \mathrm{~g}$ small $($ dia $\sim 10-15 \mathrm{~cm}$ ) hard porcelain balls and water $(130-135 \mathrm{ml})$ with a number of mill additives (chemically pure or analytical grade chemicals) separately as detailed in table 2 . In some cases, water soluble organic polymer (poly-methyl methacrylate based) was used in varying amounts from the available stock (one wt $\%$ aqueous solution) as suspending agent by replacing clay.

The details of application of the coating on metal substrates have been described by Biswas et al (1986). The adhesion of coating with the mild steel substrate was measured by a PEI adhesion meter at $2000 \mathrm{psi}$ pressure (as per IS 3972-1968). The amount of denuded metal surface gives a quantitative indication of the adhesion of the coating and bears an inverse relationship. The resulting coating (table 1, composition no. 2) which was identified to exhibit the best set of properties was characterized by X-ray diffraction (P.W.-1010 X-ray crystallographic Unit, using $\mathrm{CuK} \alpha$ radiation) and scanning electron microscope analysis (Cambridge Stereoscan S-250 Electron Microscope). The surface of the coating

Table 1. Details of compositions studied.

\begin{tabular}{lrrrrrr}
\hline & \multicolumn{5}{c}{ Constituents (parts by weight) } \\
\cline { 2 - 7 } $\begin{array}{l}\text { Compo- } \\
\text { sition no. }\end{array}$ & $\mathrm{SiO}_{2}$ & $\mathrm{~B}_{2} \mathrm{O}_{3}$ & $\begin{array}{c}\mathrm{Na}, \mathrm{K} \\
\mathrm{Li})_{2} \mathrm{O}\end{array}$ & $\begin{array}{c}\text { (Ba) } \\
\mathrm{Ca}\end{array}$ & $\mathrm{TiO}_{2}$ & $\mathrm{Ni}) \mathrm{O}$ \\
\hline 1 & 57.2 & $9 \cdot 3$ & 20.5 & 1.8 & 10.0 & 1.0 \\
2 & 54.2 & 9.2 & 19.0 & 5.1 & 9.5 & 1.0 \\
3 & 55.0 & 9.2 & 16.6 & 4.1 & 8.7 & 1.0 \\
4 & 40.0 & 12.3 & 12.6 & 2.0 & 5.9 & 1.5 \\
5 & 53.0 & 14.0 & 12.4 & 1.9 & 6.0 & 1.0 \\
6 & 52.0 & 11.8 & 14.4 & 2.5 & 8.5 & 1.0 \\
7 & 50.0 & 7.3 & 18.2 & 1.6 & 7.0 & 1.0 \\
8 & 48.0 & 8.3 & 17.7 & 2.3 & 8.5 & 1.0 \\
\hline
\end{tabular}

was also characterized by optical microscopy (Wild M3Z Stereo Microscope).

The coefficient of thermal expansion of the coating material (table 1, composition no. 2) was determined by a Shimadzu Thermal Analyser DT-30 model dilatometer.

\section{Results and discussion}

Standard commercial ground coat compositions as well as acid resistant coating materials are available in literature. But they do not fulfill all the requirements of a thin one coat coating suitable for air preheater heating elements. However, most of the properties of coating are additive in nature and depend greatly on the composition and can be tailored by suitably tailoring the composition. A series of suitably designed alkali boro silicate compositions (shown in table 1) were studied with respect to their coating properties like acid resistance, adhesion, firing temperature for application, surface finish, as well as economical viability as compared with commercially available ground coats for mild steel. The results are shown in table 2 . Composition no. 2 which was identified to have the best set of properties was used in subsequent studies during this investigation.

A number of mill additives (as detailed in table 3) were used to study their effects on the coating properties. The results as shown in table 4 indicate that with the use of various mill additives, the resulting coatings show variations in set of properties studied and may be tailored to suit other industrial applications. It is also noted that replacement of clay (the traditional suspending agent) with polymer solution resulted in reduced firing temperature without adversely affecting the surface finish and adherence of the resulting coating. The reduction in amounts of mill added quartz always resulted in reduction in acid resistance property.

For obtaining thin $(<0.2 \mathrm{~mm})$, strongly adherent $(95 \%)$ and defect free coating surface, optimum process parameters like specific gravity of the coating slip, milling fineness (particle size distribution) and mill additives were standardized. The coefficient of linear

Table 2. Results of studies on coatings obtained.

\begin{tabular}{lccll}
\hline $\begin{array}{l}\text { Compo- } \\
\text { sition no. }\end{array}$ & $\begin{array}{c}\text { Acid resistance } \\
\left.\text { (wt. loss } / \mathrm{dm}^{2}\right)\end{array}$ & $\begin{array}{c}\text { Firing } \\
\text { temperature } \\
\left({ }^{\circ} \mathrm{C}\right)\end{array}$ & $\begin{array}{c}\text { Surface } \\
\text { finish }\end{array}$ & $\begin{array}{c}\text { Relative cost } \\
\text { (comparative to } \\
\text { commercial } \\
\text { ground coat) }\end{array}$ \\
\hline 1 & $0.0-5.0$ & $840-860$ & Very good & Moderate-low \\
2 & $0 \cdot 0-5.0$ & $800-820$ & Very good & Moderate-low \\
3 & $0.0-5 \cdot 0$ & $800-820$ & Good & Moderate \\
4 & 95 & $800-820$ & Fair & Very high \\
5 & 45 & $820-840$ & Fair & High \\
6 & $0.0-5 \cdot 0$ & $860-880$ & Good & Moderate-low \\
7 & $0.0-5.0$ & $840-860$ & Good & Moderate-low \\
8 & $0.0-5.0$ & $800-820$ & Good & High \\
\hline
\end{tabular}


expansion of the best coating composition was determined to be $91.69 \times 10^{-7}$ from room temperature to $400^{\circ} \mathrm{C}$.

For application of coating by dipping method, the slip having specific gravity (1.7-1.8) and particle fineness ( $\sim 20 \%$ by weight residue over 200 mesh B.S. sieve) and mill additives in weight percent such as Quartz 20, China Clay 5 and Bentonite 1 (serial no. 1 in table 3) showed the best performance. The draining and set characteristics of the slip were finally adjusted before application of the coating by adding a few drops of an electrolyte solution (for example $10 \% \mathrm{BaCl}_{2}$ solution in water). Upon firing of the coating at $800-820^{\circ} \mathrm{C}$, the coat thickness in the range of $0.08-0.12 \mathrm{~mm}$ and acid resistance property in terms of loss in weight value
(0-5 mg per $\mathrm{dm}^{2}$ ) against boiling $\mathrm{H}_{2} \mathrm{SO}_{4}$ solution (1\%) for $2 \mathrm{~h}$ were achieved. This coating could also be fired over a wide range of temperatures $\left(780^{\circ}-900^{\circ} \mathrm{C}\right)$, with good surface finish and without any surface defect resulting from under or over firing conditions. However, the acid resistance property of the coating was found to increase with firing temperature, as was observed by Von Podesta and Runte (1987). Moreover, surface smoothness and adherence of the coating were also improved with increasing firing temperature. With poor quality of mild steel (containing higher percentage of free carbon) various surface defects appeared with increase in firing temperature.

The present coating was also evaluated for other func-

Table 3. Details of mill additives used in the study.

\begin{tabular}{|c|c|c|c|c|c|c|c|c|}
\hline $\begin{array}{l}\text { Milling } \\
\text { no. }\end{array}$ & Quartz & Feldspar & $\begin{array}{l}\text { China } \\
\text { clay }\end{array}$ & Bentonite & Borax & $\begin{array}{l}\text { Sodium } \\
\text { nitrite }\end{array}$ & $\begin{array}{l}\text { Magnesium } \\
\text { carbonate }\end{array}$ & $\begin{array}{c}\text { Polymer } \\
\text { solution }(1 \%)\end{array}$ \\
\hline 1 & 20 & - & 5 & 1.0 & - & - & - & - \\
\hline 2 & 20 & - & - & 0.5 & - & - & - & 3 \\
\hline 3 & 15 & 5 & 5 & 0.25 & - & - & - & - \\
\hline 4 & 20 & 5 & 5 & 0.25 & - & - & - & - \\
\hline 5 & 20 & - & 7 & 0.25 & - & - & - & - \\
\hline 6 & 15 & - & - & 0.5 & - & - & - & 2 \\
\hline 7 & 10 & - & - & 0.5 & - & - & - & 1 \\
\hline 8 & 20 & - & 8 & - & 0.5 & 0.5 & - & - \\
\hline 9 & 20 & - & 8 & 0.5 & 0.5 & 0.5 & 0.25 & - \\
\hline 10 & 20 & - & 8 & 0.5 & 0.5 & 0.5 & 0.4 & - \\
\hline 11 & 20 & - & 5 & - & 0.5 & 0.5 & - & - \\
\hline 12 & 20 & - & 5 & 0.5 & 0.5 & 0.5 & 0.25 & - \\
\hline 13 & 20 & - & 5 & 0.5 & 0.5 & 0.5 & 0.4 & - \\
\hline 14 & 20 & - & 5 & 0.5 & - & 0.25 & 0.25 & - \\
\hline 15 & 20 & - & 5 & $0 \cdot 5$ & 0.25 & 0.25 & - & - \\
\hline 16 & 20 & - & 5 & - & - & $0 \cdot 25$ & - & - \\
\hline
\end{tabular}

Table 4. Effect of mill additions on ultimate coating properties.

\begin{tabular}{lccll}
\hline $\begin{array}{l}\text { Milling } \\
\text { no. }\end{array}$ & $\begin{array}{c}\text { Acid resistance } \\
(\text { wt. loss in } \\
\left.\mathrm{mg} / \mathrm{cm}^{2}\right)\end{array}$ & $\begin{array}{c}\text { Firing } \\
\text { temperature } \\
\left({ }^{\circ} \mathrm{C}\right)\end{array}$ & $\begin{array}{c}\text { Surface } \\
\text { finish }\end{array}$ & Adherence* \\
\hline 1 & $0 \cdot 0-5 \cdot 0$ & $800-820$ & Very good & Very good \\
2 & $0 \cdot 0-5 \cdot 0$ & $780-800$ & Good & Very good \\
3 & $5 \cdot 0-8 \cdot 0$ & $800-820$ & Good & Good \\
4 & $5 \cdot 0-8 \cdot 0$ & $820-840$ & Fair & Good \\
5 & $5 \cdot 0-8 \cdot 0$ & $820-840$ & Fair & - \\
6 & $4 \cdot 0-6 \cdot 0$ & $780-800$ & Good & - \\
7 & $10-0-15 \cdot 0$ & $780-800$ & Good & - \\
8 & - & $820-840$ & Good & Poor \\
9 & - & $820-840$ & Fair & Poor \\
10 & - & $820-840$ & Poor & Poor \\
11 & - & $\sim 840$ & Good & Good \\
12 & - & $\sim 840$ & Good & Good \\
13 & - & $840-860$ & Vood good & Good \\
14 & $0 \cdot 0-5 \cdot 0$ & $840-860$ & Good & Very good \\
15 & $0 \cdot 0-5 \cdot 0$ & $830-850$ & Poor & Poor \\
16 & - & &
\end{tabular}

*Very $\operatorname{good}=>95 \%$, Good $=75-95 \%$ and Poor $=<75 \%$. 
tional properties, viz. resistance to boiling against different acids of varying strength, alkali, water as well as resistance to abrasion and thermal shock. The results indicate that the coating (composition no. 2 and milling no. 1) possesses good thermal shock resistance (suitable for use at elevated temperature), good abrasion resistance which increases the life of the coating against mechanical wear and tear, good alkali resistance in addition to resistance to various acids under boiling conditions (table 5). Hence this coating can also find good potentiality to increase the service life of metal components in various industrial and engineering applications such as mud pumps, gas stove parts, automobile exhaust pipes, chemical and pharmaceutical processing equipments (reactors, stirrers and valves), hot water tanks, silage storage units, etc. (von Podesta and Runte 1987).

X-ray diffraction pattern (figure 1) of the coating showed the presence of quartz and small amounts of cristobalite but scanning electron micrograph (figure 2) showed predominant amorphous matrix with scanty distribution of crystalline phases (quartz). The optical micrographs (figure 3 ) of the sub-surface structure obtained after exposure of the coating surface to boiling sulphuric acid $(20 \%)$ for $48 \mathrm{~h}$, indicated that there was neither any pin hole nor any bubble present in the coating.

The life time of the present coating for heat exchanger, where failure occurs due to chemical corrosion, has been estimated by adopting the constructed mathematical model

Table 5. Other relevant properties of acid resistant one coat enamel.

\begin{tabular}{|c|c|c|}
\hline $\begin{array}{l}\text { Serial } \\
\text { no. }\end{array}$ & Properties & Result \\
\hline 1 & Thermal shock resistance & $\begin{array}{l}550^{\circ} \mathrm{C} / \\
10 \text { cycles }\end{array}$ \\
\hline 2 & $\begin{array}{l}\text { Abrasion resistance (loss in wt.) } \\
(50,000 \text { cycles in PEI Abrasion } \\
\text { Tester })\end{array}$ & $2.0-3.0 \mathrm{mg} / \mathrm{cm}^{2}$ \\
\hline 3 & Adherence index (IS-3972-68) & $>95 \%$ \\
\hline 4 & $\begin{array}{l}\text { Acid resistance (boiling condition) } \\
\text { (loss in wt. in } \mathrm{mg}^{2} \mathrm{~cm}^{2} \text { ) } \\
\text { (a) } 2.5 \mathrm{~h} \text { in } 11 \% \mathrm{H}_{2} \mathrm{SO}_{4} \\
\text { (b) } 2.5 \mathrm{~h} \text { in } 11 \% \mathrm{HNO}_{3} \\
\text { (c) } 2.5 \mathrm{~h} \text { in } 11 \% \mathrm{HCl} \\
\text { (d) } 48 \mathrm{~h} \text { in } 20 \% \mathrm{H}_{2} \mathrm{SO}_{4} \\
\text { (c) } 2.5 \mathrm{~h} \text { in conc. } \mathrm{H}_{3} \mathrm{PO}_{4}\end{array}$ & $\begin{array}{l}5 \cdot 0 \\
5 \cdot 0 \\
15 \cdot 0-20 \cdot 0 \\
24 \cdot 0-25 \cdot 0 \\
3 \cdot 0-4 \cdot 0\end{array}$ \\
\hline 5 & $\begin{array}{l}\text { Alkali resistance (in boiling } \\
\text { condition) }(1 \% \text { tetra sodium } \\
\text { pyrophosphate solution, } \mathrm{pH}=10 \cdot 0)\end{array}$ & $2 \cdot 0-7 \cdot 0$ \\
\hline 6 & $\begin{array}{l}\text { Boiling water resistance } \\
\left(0.04 \% \mathrm{NaHCO}_{3} \text { solution) }\right. \\
\text { (a) For } 70 \mathrm{~h} \\
\text { (b) For } 149 \mathrm{~h}\end{array}$ & $\begin{array}{l}10 \cdot 0-70 \cdot 0 \\
30 \cdot 0-140 \cdot 0\end{array}$ \\
\hline
\end{tabular}

(Akhnazarova and Kafarov 1978) using Brandon's (1959) method. By considering the variable factors, viz. corrosion rate, coat thickness and concentration of surface defects, the life time of a coating can be expressed by the equation,

$$
\tau_{\mathrm{e}}=\frac{0.9 h}{k}(1-0.44 \log P),
$$

where $\tau_{\mathrm{e}}$ is the life time in years, $h$, the thickness in $\mathrm{mm}, k$, the corrosion rate in $\mathrm{mm}$ per year and $P$ the number of pores and large bubbles per unit area $\left(\mathrm{cm}^{2}\right)$ in the structure of the coating.

In the present case, because of high heat transfer requirement $h$ is $<0.20 \mathrm{~mm} ; k$ is $0.0927 \mathrm{~mm} /$ year as determined by the standard method (ISO-2733) using a solution of sulphuric acid (20\%) under boiling condition (vapour phase); $P$ is $0.002153 / \mathrm{cm}^{2}$ as measured by optical microscope. Hence, the estimated life time of the coating comes to about 4.79 years which is much superior to other reported data (Bazayants et al 1982).

\section{Conclusion}

The special vitreous enamel coating developed is corro-

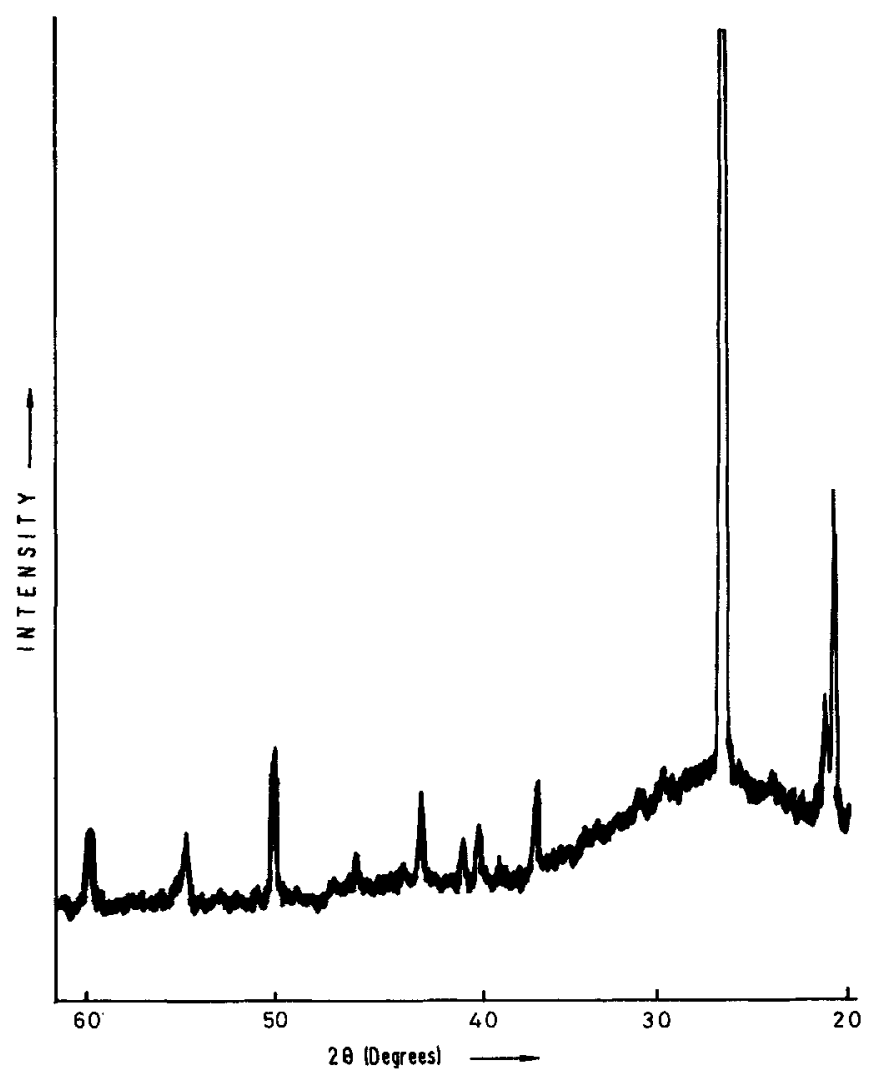

Figure 1. X-ray diffraction pattern of acid resistant coating (composition no. 2, milling no. 1). 


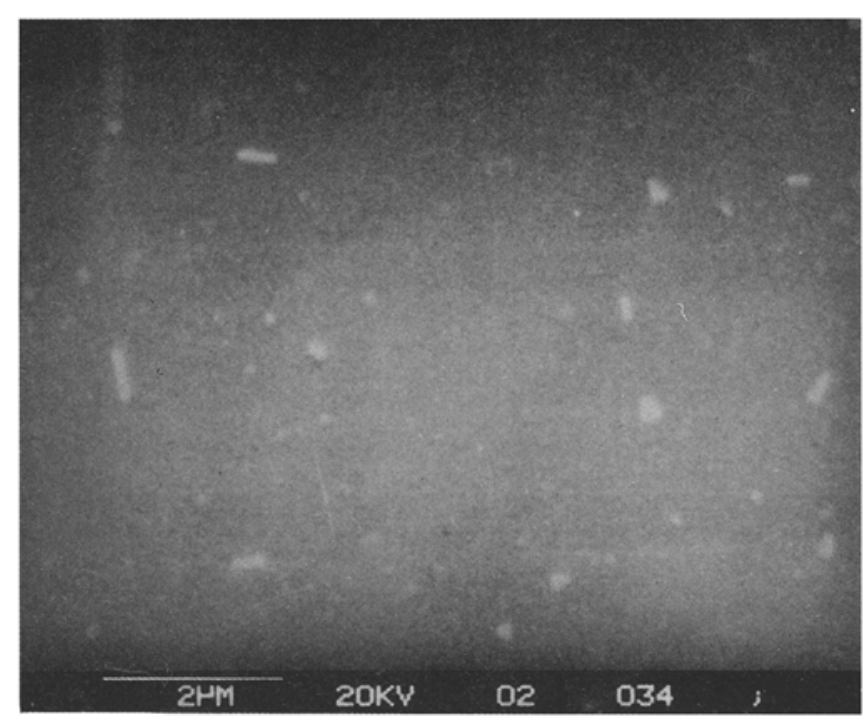

Figure 2. SEM micrograph of acid resistant coating surface.

sion resistant towards sulphuric acid condensates and a very thin layer can be applied on metallic panels $(<0.2 \mathrm{~mm})$ to comply with heat transfer requirement of waste heat recovery systems. The optimization of rheology and composition of enamel slip ensures thin and defect free application. Comparison with various test specifications of various countries establish its superior quality. Characterization with XRD, optical and scanning electron microscope proves the coating to be essentially amorphous with scanty distribution of quartz crystals. Evaluation of other physical properties using various mill additives extends its area of application. The calculation of life time using a constructed mathematical model based on Brandon's method showed the life of such coating to be $\sim 4.79$ years which is again superior to other reported results.

So, it can be concluded that this coating material is a potential candidate for use on air preheater heating elements in boilers of thermal power plants as well as for other industrial and engineering applications to prevent corrosion.

\section{Acknowledgements}

The author is thankful to Dr D Ganguli, Head and all

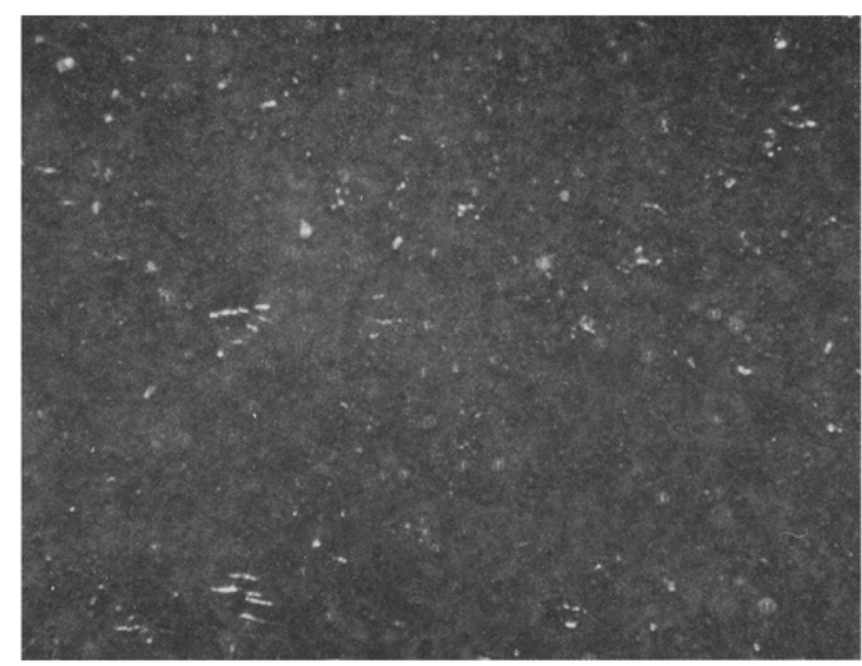

Figure 3. Optical micrograph of sub-surface of acid resistant coating $(\times 40)$.

other members of Glass-Ceramic Coating Division for various help. Thanks are also due to Dr A Chakravorty for X-ray analysis and Mrs S Sen for SEM studies.

\section{References}

Ahmad K J, Yunus M, Singh S N, Srivastava K, Singh N, Pandey V and Misra J 1991 CSIR News 41170

Akhnazarova S L and Kafarov V V 1978 Optimization of experiments in chemistry and chemical technology (Moscow: Vysshaya Shokola)

Andrews A I 1961 Porcelain enamels (lllinois, USA: The Garrard Press)

Bazayants G V, Svetlichnyi V A, Strontinskii A A and Demhuck V V 1982 Glass \& Ceramics 3926

Biswas K K, Datta S, Das S K, Ghose M C, Mazumdar A and Ray N 1986 Trans. Indian Ceram. Soc. 4543

Bouse V. Krajina A and Moravic A 1980 Vit. Enameller 31 12

Brandon D 1959 ISA Journal 6

ISO-2733 Enamels, glass and porcelain, instrument for testing acid and neutral liquids and their vapour

Kraaijveld T and Gazo L 1988 Ceram. Engg. Sci. Proc. 9471 Phipps K J 1985 Vit. Enameller 361

Von Podesta W and Runte W 1987 Mitt. Ver Deutsch Email Fach. 35129 